\title{
Senecio vulgaris L. recorded as a new host plant for the root-knot nema- tode Meloidogyne luci
}

\author{
Nik SUSIČ ${ }^{1}$, Saša ŠIRCA ${ }^{1}$, Gregor UREK ${ }^{1}$, Barbara GERIČ STARE ${ }^{1,2}$
}

Received February 10, 2020; accepted April 27, 2020.

Delo je prispelo 10. februarja 2020, sprejeto 27. aprila 2020.

Senecio vulgaris L. recorded as a new host plant for the rootknot nematode Meloidogyne luci

Abstract: Meloidogyne luci is a polyphagous plant parasitic nematode species with a potential to cause great losses in agricultural production. $M$. luci can parasitize over thirty important crop species as well as ornamentals, herbs and weeds. In this report we documented a weed plant common groundsel (Senecio vulgaris L.) as a new naturally-infected host species which could act as a reservoir for this pest.

Key words: root-knot nematode; Meloidogyne luci; weed; host plant; Senecio vulgaris; common groundsel; reservoir
Dokumentiranje nove gostiteljske rastline Senecio vulgaris L. za rastlinsko parazitsko ogorčico Meloidogyne luci

Izvleček: Meloidogyne luci je polifagna rastlinsko parazitska ogorčica, ki je zmožna povzročiti velike izgube v kmetijski proizvodnji. Ogorčica $M$. luci lahko namreč parazitira prek trideset pomembnih kmetijskih rastlinskih vrst kot tudi okrasne rastline, zelišča in plevele. $\mathrm{V}$ tem prispevku smo dokumentirali plevelno rastlino navadni grint (Senecio vulgaris L.) kot novo, naravno okuženo gostiteljsko rastlino, ki lahko služi kot rezervoar za omenjenega škodljivca.

Ključne besede: ogorčice koreninskih šišk; Meloidogyne luci; plevel; gostiteljska rastlina; Senecio vulgaris; rezervoar

1 Agricultural Institute of Slovenia, Plant Protection Department, Ljubljana, Slovenia

2 Corresponding author, e-mail: barbara.geric@kis.si 


\section{SHORT COMMUNICATION}

Meloidogyne luci Carneiro et al. 2014 is a recently described root-knot nematode species with a potential to cause great losses in agricultural production (Carneiro et al., 2014). This plant parasitic nematode is prevalent in South America, Europe and Asia as its presence was documented in Argentina, Bolivia, Brazil, Chile, Ecuador, Greece, Guatemala, Iran, Italy, Portugal, Slovenia and Turkey (reviewed in Carneiro et al., 2014; Janssen et al., 2016; Maleita et al., 2018; reviewed in Gerič Stare et al., 2017). Its distribution may be even broader than reported as species identification is challenging and was misidentified as Meloidogyne ethiopica Whitehead,1968, in the past (Gerič Stare et al., 2017, 2019). Important crop plants such as potato (Solanum tuberosum L.), maize (Zea mays L.) and tomato (Solanum lycopersicum L.) are host plants for M. luci (Strajnar et al., 2011; Conceição et al., 2012; Santos et al., 2019; Maleita et al., 2018), which could have serious impact for agricultural production in Europe and world-wide. This polyphagous pest can further parasitize numerous crop species such as okra (Abelmoschus esculentus (L.) Moench), kiwifruit (Actinidia deliciosa (A.Chev.) C.F.Liang \& A.R.Ferguson), onion (Allium cepa L.), celery (Apium graveolens L.), chard (Beta vulgaris var. cicla (L.) Schuebl. \& G.Martens), beet (Beta vulgaris var. conditiva L.), cabbage (Brassica oleracea var. capitate L.), cauliflower (Brassica oleracea var. botrytis L.), kohlrabi (Brassica oleracea var. gongylodes L.), broccoli (Brassica oleracea var. italica Plenck), pepper (Capsicum annuum L.), endive (Cichorium endivia L.), chicory (Cichorium intybus var. foliosum L.), melon (Cucumis melo L.), watermelon (Citrullus lanatus (Thunb.) Matsum. \& Nakai); cucumber (Cucumis sativus L.), car- rot (Daucus carota L.), buckwheat (Fagopyrum esculentum Moench), florence fennel (Foeniculum vulgare Mill. ssp. vulgare var. azoricum (Mill.) Thell.), soybean (Glycine max (L.) Merr.), sunflower (Helianthus annuus L.), barley (Hordeum vulgare L.), lettuce (Lactuca sativa L.), lucerne (Medicago sativa L.), tobacco (Nicotiana tabacum L.), rice (Oryza sativa L.), common bean (Phaseolus vulgaris L.), pea (Pisum sativum L.), yakon (Smallanthus sonchifolius (Poepp.) H.Rob.), peach (Prunus persica (L.) Batsch), radish (Raphanus sativus L. var. radicula), aubergine (Solanum melongena L.), spinach (Spinacia oleracea L.), grapevine (Vitis vinifera L.) and sweet corn (Zea mays L. var. saccharata) (Strajnar et al., 2009; Carneiro et al., 2014; Bellé et al., 2016). M. luci can also thrive on ornamentals such as snapdragon (Antirrhinum majus L.), cabbage-palm (Cordyline australis (G.Forst.) Endl.), sedum (Hylotelephium spectabile (Boreau) H.Ohba), lavender (Lavandula angustifolia Mill.) and rose (Rosa sp. L.), herb curled dock (Rumex patientia L.) and weed creeping woodsorrel (Oxalis corniculata L.) (Strajnar et al., 2009; Carneiro et al., 2014; Santos et al., 2019). As there is a great concern that this pest could spread to new areas with suitable hosts and climate conditions, the species was included in the EPPO Alert list of harmful organisms (EPPO, 2017).

We have tested efficiency of bionematicide VOTi$\mathrm{VO}^{\mathrm{mm}}$ (Bayer CropScience AG) based on bacteria Bacillus firmus Bredemann and Werner, 1933, for the protection of tomato plants against infestation with M. luci (Susič et al., 2020; Sirca et al., 2019). The test was conducted in the microplots at the site of Agricultural Institute of Slovenia from April to September in 2018 and 2019. At the end of a growing season 2019 (114 days after nematode infestation) when tomato plants were uprooted and evaluated

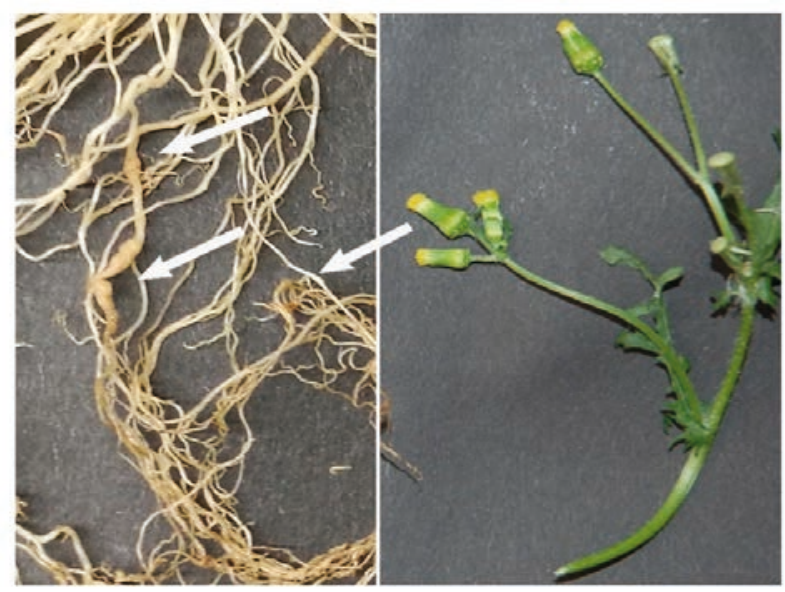

Figure 1: Senecio vulgaris recorded as a new host plant for the root-knot nematode Meloidogyne luci. Left: Roots of S. vulgaris infested with the root-knot nematode M. luci; arrows point to nematode infestation in the host roots. Right: Above ground part of the plant shows no symptoms of nematode infestation. 
for nematode infestation several weed plants were found growing in the microplots as well. The weed was identified as common groundsel (Senecio vulgaris L.) based on morphological characters. Typical root-knot nematode infestation symptoms were observed on $S$. vulgaris roots (Figure 1). Identity of nematode females dissected from galls was confirmed as $M$. luci using isoenzyme electrophoresis as described previously by Strajnar et al. (2009).

While S. vulgaris L. is a documented host plant for several Meloidogyne species such as Meloidogyne microtyla Mulvey et al., 1975 (Townshend at al., 1984), Meloidogyne incognita (Kofoid \& White, 1919) Chitwood 1949 (Amin, 1994), Meloidogyne hapla Chitwood, 1949 (Bélair \& Benoit, 1996) and Meloidogyne chitwoodi Golden, O’Bannon, Santo \& Finley, 1980 (Kutywayo \& Been, 2006), this is a first report of S. vulgaris L. being a host plant for M. luci as well. S. vulgaris is a widely distributed weed and ruderal species. The significance of description of a new naturally-infected host of $M$. luci is a fact that the weed species $S$. vulgaris $\mathrm{L}$. could act as a reservoir of this plant pathogenic nematode in agricultural production settings. The producers using resistant crop varieties like tomato bearing the $M i$ resistance gene to control $M$. luci infestation in greenhouses or fields should therefore be aware that this widely spread weed could maintain nematode population.

Acknowledgments: This research was partially funded by ARRS (grants no. MR 38128, P4-0072, V41602) and MKGP (V4-1602).

\section{REFERENCES}

Amin, A W. (1994). Root-knot nematodes (Meloidogyne spp.) in Hungary. EPPO bulletin, 24(2), 417-422. https://doi. org/10.1111/j.1365-2338.1994.tb01399.x

Bélair, G., Benoit, D. L. (1996). Host Suitability of 32 Common Weeds to Meloidogyne hapla in Organic Soils of Southwestern Quebec. Supplement to Journal of Nematology, 28(4S), 643-647.

Bellé, C., Brum, D., Groth, M. Z., Barros, D. R., Kaspary, T. E., Schafer, J. T., Gomes, C. B. (2016). First Report of Meloidogyne luci Parasitizing Glycine max in Brazil. Plant Disease, 100 (10), 2174. https://doi.org/10.1094/PDIS-05-16-0624-PDN

Carneiro, R. M. D. G., Correa, V. R., Almeida, M. R. A., Gomes, A. C. M. M., Deimi, A. M., Castagnone-Sereno, P., Karssen, G. (2014). Meloidogyne luci n. sp. (Nematoda: Meloidogynidae), a root-knot nematode parasitising different crops in Brazil, Chile and Iran. Nematology, 16(3), 289-301. https://doi. org/10.1163/15685411-00002765

Conceição, I. L., Tzortzakakis, E. A., Gomes, P., Abrantes, I., da Cunha, M. J. (2012). Detection of the root-knot nematode $M e$ loidogyne ethiopica in Greece. European Journal of Plant Pathology, 134, 451-457. https://doi.org/10.1007/s10658-012-0027-0

EPPO. (2017). Alert List: addition of Meloidogyne luci together with M. ethiopica. EPPO Reporting Service, No. 11-2017. Retrieved from https://gd.eppo.int/reporting/article-6186. Accessed 2 October 2019.
Gerič Stare, B. G., Aydinli, G., Devran, Z., Mennan, S., Strajnar, P., Urek, G., Širca, S. (2019). Recognition of species belonging to Meloidogyne ethiopica group and development of a diagnostic method for its detection. European Journal of Plant Pathology, 154(3), 621-633. https://doi.org/10.1007/s10658-019-01686-2

Gerič Stare, B. G., Strajnar, P., Susič, N., Urek, G., Širca, S. (2017). Reported populations of Meloidogyne ethiopica in Europe identified as Meloidogyne luci. Plant Disease, 101(9), 1627-1632. https://doi.org/10.1094/PDIS-02-17-0220-RE

Janssen, T., Karssen, G., Verhaeven, M., Coyne, D., Bert, W. (2016). Mitochondrial coding genome analysis of tropical root-knot nematodes (Meloidogyne) supports haplotype based diagnostics and reveals evidence of recent reticulate evolution. Scientific reports, 6, 22591, https://doi.org/10.1038/srep22591

Kutywayo, V. \& Been, T. (2006). Host status of six major weeds to Meloidogyne chitwoodi and Pratylenchus penetrans, including a preliminary field survey concerning other weeds. Nematology 8(5), 647-657. https://doi.org/10.1163/156854106778877839

Maleita, C., Esteves, I., Cardoso, J. M. S., Cunha, M. J., Carneiro, R. M. D. G., Abrantes, I. (2018). Meloidogyne luci, a new rootknot nematode parasitizing potato in Portugal. Plant Pathology, 67(2), 366-376. https://doi.org/10.1111/ppa.12755

Santos, D., Correia, A., Abrantes, I., Maleita, C. (2019a). New hosts and records in Portugal for the root-knot nematode Meloidogyne luci. Journal of Nematology, 51, https://doi.org/10.21307/ jofnem-2019-003

Santos, D., Martins da Silva, P., Abrantes, I., Maleita, C. (2020). Detection of Mi gene and reproduction of Meloidogyne luci and M. ethiopica on tomato genotypes. European Journal of Plant Pathology, 156, 571-580. https://doi.org/10.1007/s10658-01901907-8

Strajnar, P., Širca, S., Gerič Stare, B. Urek, G. (2009). Characterization of the root-knot nematode, Meloidogyne ethiopica Whitehead, 1968, from Slovenia. Russian Journal of Nematology, 17(2), 135-142.

Strajnar, P., Širca, S., Knapič, M. Urek, G. (2011). Effect of Slovenian climatic conditions on the development and survival of the root-knot nematode Meloidogyne ethiopica. European Journal of Plant Pathology, 129(1), 81-88. https://doi.org/10.1007/ s10658-010-9694-x

Susič, N., Žibrat, U., Sinkovič, L., Vončina, A., Razinger, J., Knapič, M., Sedlar, A., Širca, S., Gerič Stare, B. (2020). From genome to field - Observation of the multimodal nematicidal and plant growth-promoting effects of Bacillus firmus I-1582 on tomatoes using hyperspectral remote sensing. Plants, Accepted for publication. https://doi.org/10.3390/plants9050592

Širca, S., Gerič Stare, B., Strajnar, P., Susič, N. (2019). Uporaba metod z nizkim tveganjem za varstvo zelenjadnic (CRP V4-1602), Izroček 14: poročilo o učinkovitosti komercialnega biopesticida za zatiranje fitoparazitskih ogorčic iz rodu Meloidogyne, Kmetijski inštitut Slovenije, Ljubljana, 14.9.2019, Retrieved from https://www.ivr.si/wp-content/uploads/2018/12/IZROCEK14-Dvoletno-presku\%C5\%A1anje-bionematocida-Votivo.pdf

Townshend, J.L., Potter, J.W., Daidson T.R. 1984. Some monocotyledonous and dicotyledonous hosts of Meloidogyne microtyla. Plant Disease, 68(1), 7-10. https://doi.org/10.1094/PD-68-7 